\title{
Effects of some watershed characteristics on water yield in the West Black Sea Region of northern Turkey
}

\author{
Efectos de algunas características de las cuencas hidrográficas \\ sobre el rendimiento hídrico en la región occidental del Mar Negro del norte de Turquía
}

\author{
Hayati Zengin a*, Mehmet Özcan ${ }^{\text {b }}$, Ahmet Salih Değermenci a , Tarık Çitgez ${ }^{\text {b }}$ \\ *Corresponding author: ${ }^{a}$ Düzce University, Faculty of Forestry, Department of Forest Management and Planning, Düzce, \\ Turkey, phone: +90 533722 5094, hayatizengin@duzce.edu.tr \\ ${ }^{\text {b }}$ Düzce University, Faculty of Forestry, Department of Watershed Management, Düzce, Turkey.
}

\begin{abstract}
SUMMARY
This paper presents the effect of some watershed characteristics on water yield based on two-year measurements (2015-2016) realized at 29 watersheds. Although, there are several factors affecting the runoffs, we tried to eliminate some and focused on watershed characteristics by choosing the watersheds as near as to each other in the same hydro-climatic zone. These are relatively small watersheds (8.6-449.3 ha) at the mountainous and forested areas around Düzce city, Turkey. Elevation of most watersheds, which is effective on precipitation, is above $1,000 \mathrm{~m}$ and covered by snow in winter. Regression models between water yield or runoff coefficient based on water yield/precipitation ratio and some watershed characteristics can be important to estimate the amount of water and manage the forest for its hydrologic function. In this study, the effect of watershed area, form factor, mean slope, drainage density, elevation, circularity and elongation ratios on water yield and runoff coefficient was analyzed by multiple linear regression analyses. While there is not a significant relation between runoff coefficient and watershed characteristics, we constructed a significant regression model for estimating water yield depending on watershed characteristics. Watershed size, elevation, form factor and elongation ratios are found as effective variables on water yield. When other variables (ratio of circularity, mean slope, drainage density) were added, adjusted $R^{2}$ and significance of the model was decreased. Results showed that some watershed characteristics have a significant effect on water yield, and equations based on these characteristics can be used in forest management or policy making in determining the priority of watersheds for water production.
\end{abstract}

Key words: watershed size, form factor, water yield, regression model, Turkey.

\section{RESUMEN}

Este artículo presenta el efecto de algunas características de 29 cuencas hidrográficas sobre el rendimiento del agua con base en mediciones de dos años (2015-2016). No obstante que hay varios factores que afectan las escorrentías, el estudio se concentró en las características de las cuencas hidrográficas, eligiendo cuencas cercanas unas de otras en la misma zona hidroclimática. Fueron cuencas pequeñas (8,6-449,3 ha) en áreas montañosas y boscosas alrededor de la ciudad de Düzce, Turquía. La mayoría de las cuencas presentó elevación sobre $1.000 \mathrm{~m}$ y cubierta de nieve invernal. Mediante análisis de regresión lineal múltiple se evaluó el efecto de: área de la cuenca, factor de forma, pendiente media, densidad de drenaje, elevación, circularidad y relaciones de elongación en el rendimiento de agua y el coeficiente de escorrentía. Si bien no hubo relación significativa entre el coeficiente de escorrentía y las características de la cuenca, se construyó un modelo de regresión significativo para estimar el rendimiento del agua dependiendo de las características de la cuenca. El tamaño de la cuenca, la elevación, el factor de forma y las relaciones de elongación fueron variables explicativas del rendimiento del agua. Al añadir otras variables (relación de circularidad, pendiente media, densidad de drenaje) se redujo la significancia del modelo. Algunas características de las cuencas hidrográficas tuvieron efecto significativo en el rendimiento del agua y las ecuaciones basadas en ellas pueden ser utilizadas en el manejo forestal o en la formulación de políticas para determinar prioridades de cuencas hidrográficas para la producción de agua.

Palabras clave: tamaño de la cuenca, factor de forma, rendimiento del agua, modelo de regresión, Turquía.

\section{INTRODUCTION}

Water is an indispensable part of human life and many activities. Although being a renewable natural source and on a global scale considered within the group of infini- te natural resources, it is in fact a finite resource in terms of region or quality. Together with its importance for life, much of it can be hazardous as floods. Therefore, there are efforts to control the potential amount of water between usable limits. Some dams or regulators on rivers or some 
forestry activities like plantations or cuttings in the watersheds are to manage the amount of available water.

The presence of water in a region is not only dependent on rainfall. For that matter terrain, geological and lithological base, soil properties, temperature, the rainfall patterns and their distribution into seasons and similar factors play an important role as well (Çepel 1993). Some attributes within the watershed are variable and can be managed for water yield. These can be the ratio of the forest area, the standing stock or basal area, or closure of the forest etc., which can be arranged based on the hydrological objectives. Besides these variables, theoretically it is not possible to change some attributes like slope, the elevation above sea level of the watershed, form factor, drainage density and ratio of elongation or circulation, all of which are known as watershed characteristics. However these characteristics cannot be changed, they can be effective on water yield or runoff coefficients of watersheds and can be used to estimate the water yield of each watershed.

Watershed characteristics and forest structure over the watershed influence water budget elements (infiltration, interception, evapotranspiration, surface and subsurface flow) and play a role on the quantity and quality of water that reaches the streams and through them collected in areas such as dams and ponds. Although known to be effective in hydrological processes of these mentioned factors, the amount of available knowledge is not sufficient to establish a relationship between these factors and the quantity or quality characteristics of the water (Price 2011). Understanding the relationships and the acquisition of various data is a prerequisite for successful planning, to meet the demand from society, for various forestry services. Information about watershed characteristics can serve forest management or policy by showing where to concentrate the forestry activities. The results of the effects of forestry activities to water yield are different in the watersheds having different watershed characteristics. Consequently, watershed characteristics can be used as a term showing the suitability or unsuitability of watersheds for water production or where and in which intensity to allocate the forestry activities.

Considering the fact that putting forth all the associated factors with one study would be problematic, the issue is addressed by focusing certain specific points. Watershedscale studies of the potential effect of land use changes on water quality or quantity are essential to minimizing water pollution or sustainable use of water resources (Yuan et al. 2015). In this context, while some researchers investigated the effect of vegetation and land use or change in different regions (Bosch and Hewlett 1982, Sun et al. 2005, Roberts 2016), some other researchers sought to demonstrate the impact of watershed properties on the quality or yield of water (Pilgrim et al. 1982, Kotak et al. 2005, Price et al. 2011, Meraj et al. 2015). In addition, there are studies on development, calibration or testing of some models. The scale can be estimated by using models that consider to- pography, soil properties, land cover and land use, erosion, sediment transport, runoff or peak discharge at the watershed (Bisantino et al. 2015).

The scientific aspects of watershed processes and the dynamics of flows need to be understood to achieve an effective water policy and management (Price 2011). Although there are various studies, general information about the effects of watershed characteristics cannot be given because there are many watershed characteristics and their effects on water yield can change by the interactions between them and other factors such as climate or geology. The geomorphology of watersheds impacts base flow, nevertheless there is no consensus on which geomorphic parameters have more effect. To understand the watershed system, there is a need for regional researches to carry out investigations with a large number of different perspectives (Price 2011). As an example, Bao and Laituri (2013) investigated the effects of some characteristics on the flow rates in 15 watersheds belonging to different ecological zones and stated that the watershed area and the form factor had a significant impact on the flow rates.

Understanding the effective factors on runoffs is important for sustainably managing water resources. By this way, it is possible to take some measures to prevent floods or to manage forests for water production. Watershed characteristics can be used as a benchmarking tool to compare watersheds to decide where to concentrate for water production. Thus, zoning strategies can be generated in forest management and regression models can be used in optimization of forest outputs or trade-off analyses. The aim of this study is to put forward whether the characteristics of the watersheds can influence water yield in the mountainous areas covered with forests in the western Blacksea region of Turkey, which has a humid climate and is rich in water resources. It is important to put the relation with a regression model, which can be used to estimate the water yield from any watershed. By this way, it can be possible to make some priority ordering among watersheds in terms of their water yields. For this purpose, water yield measurements were made in the selected 29 sub watersheds for two years and their relations with some watershed characteristics were investigated by the regression analyses.

\section{METHODS}

Study site. The study was conducted in Turkey's western Black Sea Region, in 29 watersheds, which are situated in the north and southeast of Düzce province and are located between $40^{\circ} 37$ ' $18^{\prime}$ " $-41^{\circ} 06^{\prime}$ ' $58^{\prime \prime}$ "North latitude and $30^{\circ} 50$ ' 14 '" $-31^{\circ} 51$ ' 13 ' east longitude (figure 1). Düzce is founded upon a plain surrounded by mountains. While average height of Düzce is 140 meters above sea level, the height at the mouth points of the watersheds forming the study area ranges between 528-1,526 m above sea level.

Düzce province has a humid climate medium temperature (mesothermal) according to Thornthwaite classifi- 
cation system, and in summer, it presents an ocean climate type with moderate water deficit (B1B2'sb4'). The average annual rainfall is $818.4 \mathrm{~mm}$ and most rainfall is in March and October. The average annual temperature is $13.2^{\circ} \mathrm{C}$. The coldest month of the year is January with $3.9^{\circ} \mathrm{C}$ and the warmest month of the year is July with $22.6{ }^{\circ} \mathrm{C}$ (Yavuz 2013).

Düzce plain is a lake bottom which is covered by fourth era alluvium. The mountainous regions of south of Düzce, where most of the studied watersheds are located, have formations of sandstone-conglomerate, marn, tuffite (volcanic sandstone) from the tertiary period. Moreover, in the eastern and south eastern part of the province, where a portion of the watersheds take place, there are formations of sandstone-conglomerate-marn-tuffite (volcanic sandstone) and formations which consist of claystone, argillaceous limestone-marn with intermediate level siltstone, and reef limestone (Özmen 2000).

Watersheds are all located in mountainous areas and all of them have a forest-covered area of over $90 \%$. The main tree species that make up the forest vegetation of Düzce
Province are oak (Quercus sp.), beech (Fagus orientalis Lipsky), fir (Abies nordmanniana Spach) and Scotch pine (Pinus sylvestris L.) (Y1ldı et al. 2010). Oak can be found in the lower altitude watershed areas, whereas beech and fir are located in middle and higher-level watersheds. In upper watersheds, Scotch pine is participating in the mixture as well.

Characteristics of watersheds. ArcGIS 10.4 software was used to determine the characteristics of watersheds. Some features of 1/25,000 scale topographic maps, on which the watersheds are located, were digitalized and in this way the data for watersheds were produced. After determining the entire watershed boundaries on these maps and digital elevation model, their accuracy was also verified on field. This study addresses the watershed characteristics, watershed area, circularity ratio, elongation ratio, form factor, drainage intensity, mean slope and elevation. Information on all watersheds is given in table 1. The formulas (Özhan 2004) used in the calculation of watershed characteristics are given below.

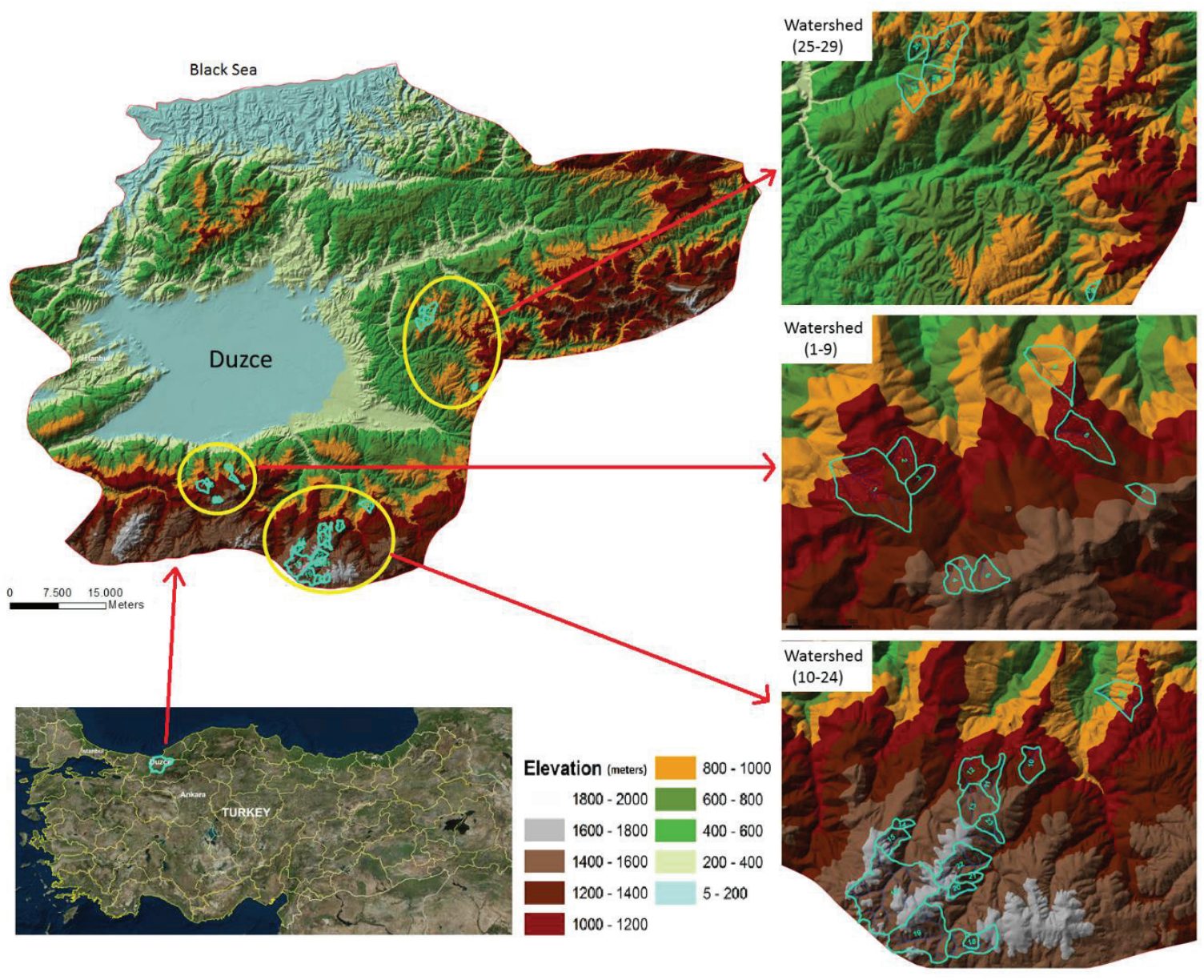

Figure 1. Geographic position of watersheds.

Ubicación geográfica de las cuencas hidrográficas. 
Table 1. Information on the characteristics of the watersheds.

Información sobre las características de las cuencas hidrográficas.

\begin{tabular}{|c|c|c|c|c|c|c|c|c|c|}
\hline $\begin{array}{l}\text { Watershed } \\
\text { No }\end{array}$ & $\begin{array}{c}\text { Area } \\
\text { (ha) }\end{array}$ & $\begin{array}{l}\text { Length } \\
(\mathrm{m})\end{array}$ & $\begin{array}{l}\text { Width } \\
\text { (m) }\end{array}$ & $\begin{array}{l}\text { Circularity } \\
\text { ratio }\end{array}$ & $\begin{array}{l}\text { Elongation } \\
\text { ratio }\end{array}$ & $\begin{array}{l}\text { Form } \\
\text { factor }\end{array}$ & $\begin{array}{c}\text { Drainage } \\
\text { density }\end{array}$ & $\begin{array}{c}\text { Mean } \\
\text { slope (\%) }\end{array}$ & $\begin{array}{c}\text { Elevation } \\
\text { (m) }\end{array}$ \\
\hline 1 & 104,7 & 1,673 & 1,094 & 0,7 & 0,7 & 0,7 & 4,6 & 42,4 & 924 \\
\hline 2 & 21,7 & 757 & 524 & 0,8 & 0,7 & 0,7 & 4,4 & 37,5 & 1,097 \\
\hline 3 & 12,6 & 588 & 241 & 0,8 & 0,7 & 0,4 & 3,1 & 41,6 & 1,150 \\
\hline 4 & 11,2 & 526 & 332 & 0,7 & 0,7 & 0,6 & 2,9 & 37,6 & 1,347 \\
\hline 5 & 8,8 & 610 & 191 & 0,5 & 0,5 & 0,3 & 4,0 & 35,9 & 1,346 \\
\hline 6 & 19,7 & 587 & 613 & 0,7 & 0,9 & 1,0 & 3,2 & 36,6 & 1,373 \\
\hline 7 & 8,0 & 539 & 198 & 0,7 & 0,6 & 0,4 & 12,0 & 54,0 & 1,294 \\
\hline 8 & 37,0 & 1,023 & 492 & 0,6 & 0,7 & 0,5 & 4,0 & 50,2 & 1,035 \\
\hline 9 & 42,6 & 1,174 & 607 & 0,6 & 0,6 & 0,5 & 3,9 & 50,8 & 758 \\
\hline 10 & 63,1 & 1,187 & 903 & 0,7 & 0,8 & 0,8 & 3,5 & 35,5 & 1,105 \\
\hline 11 & 50,8 & 1,710 & 513 & 0,4 & 0,5 & 0,3 & 4,1 & 33,5 & 1,180 \\
\hline 12 & 176,7 & 3,594 & 1,305 & 0,5 & 0,4 & 0,4 & 3,7 & 30,8 & 1,176 \\
\hline 13 & 108,6 & 1,399 & 1,273 & 0,7 & 0,8 & 0,9 & 2,3 & 26,1 & 1,351 \\
\hline 14 & 15,9 & 746 & 316 & 0,6 & 0,6 & 0,4 & 4,2 & 39,5 & 1,433 \\
\hline 15 & 51,6 & 1,115 & 912 & 0,7 & 0,7 & 0,8 & 4,3 & 38,2 & 1,451 \\
\hline 16 & 447,1 & 2,732 & 2,437 & 0,6 & 0,9 & 0,9 & 2,7 & 34,4 & 1,471 \\
\hline 17 & 17,4 & 452 & 505 & 0,9 & 1,0 & 1,1 & 3,8 & 28,9 & 1,526 \\
\hline 18 & 111,7 & 1,503 & 904 & 0,6 & 0,8 & 0,6 & 3,9 & 32,2 & 1,472 \\
\hline 19 & 230,2 & 2,074 & 1,769 & 0,7 & 0,8 & 0,9 & 3,3 & 31,5 & 1,458 \\
\hline 20 & 26,8 & 914 & 512 & 0,6 & 0,6 & 0,6 & 3,3 & 35,2 & 1,435 \\
\hline 21 & 22,7 & 933 & 352 & 0,6 & 0,6 & 0,4 & 17,3 & 32,1 & 1,405 \\
\hline 22 & 128,5 & 1,931 & 1,546 & 0,6 & 0,7 & 0,8 & 1,0 & 28,5 & 1,394 \\
\hline 23 & 39,4 & 1,113 & 613 & 0,6 & 0,6 & 0,6 & 3,9 & 31,5 & 1,380 \\
\hline 24 & 112,1 & 1,715 & 1,206 & 0,8 & 0,7 & 0,7 & 3,5 & 42,2 & 650 \\
\hline 25 & 77,8 & 1,379 & 844 & 0,7 & 0,7 & 0,6 & 3,1 & 45,9 & 528 \\
\hline 26 & 35,1 & 916 & 577 & 0,8 & 0,7 & 0,6 & 3,1 & 39,9 & 576 \\
\hline 27 & 132,7 & 1,886 & 1,421 & 0,6 & 0,7 & 0,8 & 4,1 & 38,9 & 660 \\
\hline 28 & 71,8 & 1,070 & 1,005 & 0,9 & 0,9 & 0,9 & 3,8 & 42,4 & 662 \\
\hline 29 & 14,0 & 779 & 294 & 0,5 & 0,5 & 0,4 & 3,5 & 41,6 & 757 \\
\hline
\end{tabular}

Form Factor $(F)=\frac{B}{L}$

Drainage Density $\left(D_{d}\right)=\frac{L_{t}}{A}$

Circularity ratio $(\mathrm{Rc})=\frac{4 \pi A}{P^{2}}$

Elongation ratio $(\mathrm{Re})=\frac{2}{\mathrm{~L}}\left(\frac{A}{\pi}\right)^{0.5}$

B: Transverse length of the watershed $(\mathrm{km})$

L: Length of the watershed $(\mathrm{km})$

Lt: Total length of permanent and intermittent streams $(\mathrm{km})$

A: Watershed area $\left(\mathrm{km}^{2}\right)$

$\mathrm{P}$ : Length of watershed perimeter $(\mathrm{km})$
The altitude of the outlet of watersheds is over $500 \mathrm{~m}$ above sea level. When the great mountain masses are taken into account, the watersheds numbered from number 1 to 24 are situated in the southern exposure and located in the north of Düzce; and watersheds from 25 to 29 are situated in the southern exposure and located in the northeast of Düzce. The areas of the watersheds ranged from 8.6 to 449.3 ha and most of them are smaller than 75 hectares. Their average mean slope ranges between 31 and $54 \%$, circularity ratio is between 0.4 and 0.9 and elongation ratio ranges between 0.4 and 1.0 .

Determination of water yield. To determine the amount of water in the watersheds, initially, water level measuring instruments (Levelogger) have been placed in the box cul- 
verts (having rectangular section areas) on the downstream of the watersheds (figure 2).

For water level measurements, Solinst 3001 LT Levelogger Junior Edge instruments were used. These are placed in locked metal cylinders for protection. Measurements were made at every 30 minutes for two years and the obtained data were transferred to laptops in different periods to analyze the water level measurement.

The velocity of water flowing from rivers in the watershed outlet, where Levelogger instruments were installed, was measured by a small current meter. Water velocity rates were measured at three different points in the stream section and the average of three points was calculated. The width of the box culverts where the Levelogger instruments were installed is constant. Moreover, cross-sectional areas were calculated which changed depending on the water level. The resulting values of velocity and cross-sectional area were put into place in the $\mathrm{Q}=\mathrm{A} \times \mathrm{V}$ flow rate formula and thus the flow rate values at the time of measurement were obtained. The values are as follows: Q: Discharge $\left(\mathrm{m}^{3} \mathrm{~s}^{-1}\right)$, A: crosssectional area $\left(\mathrm{m}^{2}\right)$ and $\mathrm{V}$ : water velocity $\left(\mathrm{m} \mathrm{sec}^{-1}\right)$. In this way, the water level-flow graph of the watershed was established by means of level and discharge measurements made at different times. Regression equations were established, which show the relationship between these two variables.

For a healthier determination of Level-flow graphs, it is necessary to perform the measurements for different water levels. To this end, velocity values related to different water levels were obtained by carrying out measurements in a two-year period, approximately every 15 days. With the help of the obtained data, level-flow graphs of each one of the 29 watersheds were created. With these graphs, regression equations were obtained, which will help to calculate the yield rate based on water level. Although the $\mathrm{R}^{2}$ values for this regression equation are higher than 0.7 for the various models such as linear, exponential and polynomial --instead of models offering the highest $R^{2}$ value, in terms of being a standard of calculations-- all the equations are determined to be linear.

Values of water level, which were saved every $30 \mathrm{mi}-$ nutes by level meter (Levelogger) instruments, were put into regression equations; thereby watershed yield was calculated every 30 minutes taking the changes in the level of water into consideration. Afterward, these are converted into monthly water yield and by adding them together, the annual water yield of each watershed was calculated. Subsequently, the two-year average annual water yield was calculated from the values of the years 2015 and 2016.

Statistical analyses. We tried to put forward the relationships between water yield and a variety of characteristics of the watersheds with the help of the multiple linear regression analysis. In these analyses, water yield is considered as a dependent variable and watershed area, circularity ratio, elongation ratio, form factor, drainage density, mean slope and elevation are considered as independent variables. To check if there is an autocorrelation among independent variables or not, Durbin-Watson test was implemented. In the regression analysis, first, the relationship between water yield and all available variables was analyzed; next, gradually, the ones presenting low-level effect were removed from the analysis.
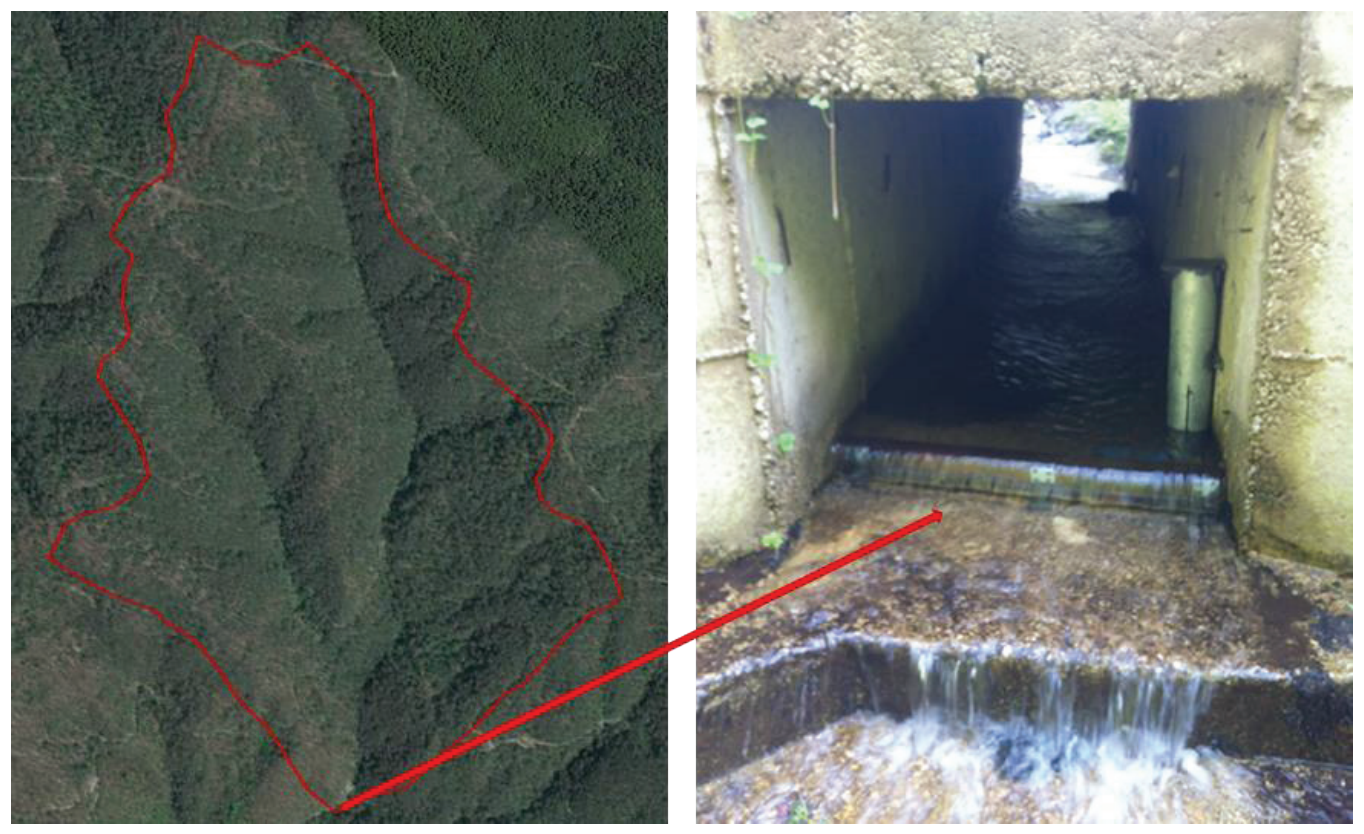

Figure 2. Box culverts at the discharge point of watersheds.

Alcantarillas en el punto de descarga de las cuencas hidrográficas. 


\section{RESULTS}

Water yield of each watershed is calculated from the equation of linear water level-flow graphs. $R^{2}$ values of the equations are generally above 0.90 and at all watersheds. A strong correlation between water level and yield was determined. Strong relationships show the availability of these equations to calculate the annual water yield of watersheds. When the two-year average annual water yield calculated using the equation was examined, maximum water yield $\left(2,795,731 \mathrm{~m}^{3}\right.$ year $\left.{ }^{-1}\right)$ is found to take place in the watershed with the largest area (449.3 ha). Minimum water yield $\left(30,446 \mathrm{~m}^{3}\right.$ year $\left.^{-1}\right)$ occurred in one of the smallest watersheds (12.8 ha).

The multiple linear regression analysis was used to determine the relationship between the watershed characteristics and the average annual water yield obtained from these watersheds. In the multiple linear regression analysis, Adjusted $R^{2}$ value of 0.92 was found. This value increases if the added variables are related to the model. Accordingly, $92 \%$ of the change in the dependent variable is explained by variables that have been included in the model. The obtained Durbin-Watson test value of 1.75 shows that there is no autocorrelation among independent variables. According to the variance analysis table values, it can be seen that, as a whole, the model is significant at all levels $(P<0.01)$. The mathematical model of multiple linear regression model obtained as a result of the statistical analysis is given in equation 1.
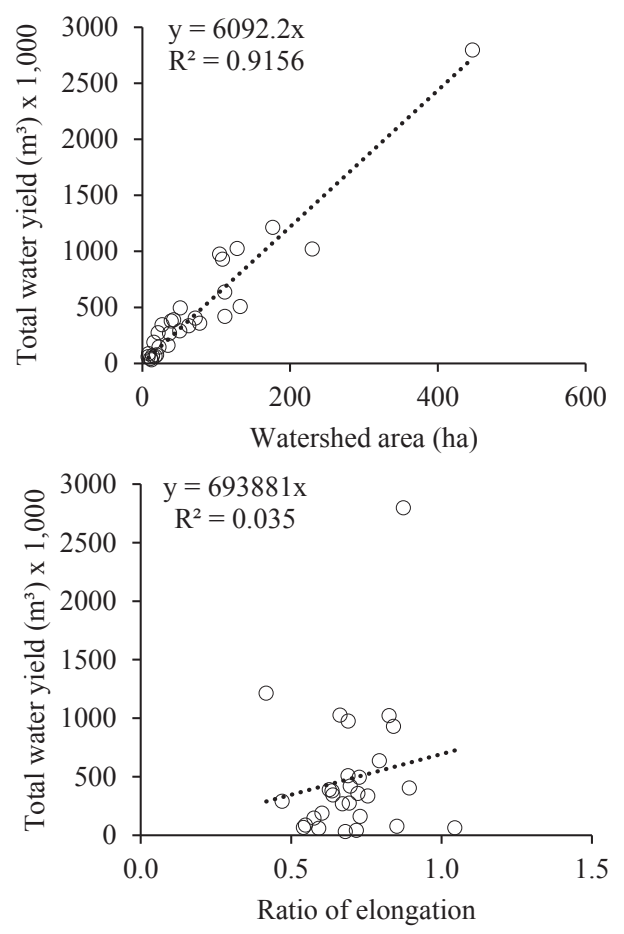

$W Y=106088+5873.5 A-610019.5 R e+256770.2 F+162.8 H \quad[1]$

WY: Water yield $\left(\mathrm{m}^{3}\right.$ year $\left.^{-1}\right)$,

$A$ : Watershed area (ha),

$R e$ : Ratio of elongation,

$F$ : Form factor,

$H$ : Elevation above sea level (m).

As a result of multiple linear regression analysis, a relationship has been observed between the watersheds total water yield $\left(\mathrm{m}^{3}\right.$ year $\left.{ }^{-1}\right)$ and watershed area (ha), ratio of elongation, form factor and elevation $(\mathrm{m})$. When other measured parameters (ratio of circularity, mean slope and drainage density) are added to the equation, the $R^{2}$ value and the significance of the model decrease. According to the model results, a positive correlation is observed between water yield and values of area, form factor and elevation. In addition, bivariate plots of water yield and watershed characteristics are presented in figure 3 . While the model as a whole is significant, the form factor, ratio of elongation and elevation do not have a significant effect on water yield when they are evaluated separately and individually. Only the watershed area is significantly effective on water yield.

Although there is an important relationship between watershed characteristics and the total amount of water getting out of the watershed, it is observed that on the analysis of runoff coefficient, watershed characteristics do not have a significant impact. In addition to this, $22 \%$ of
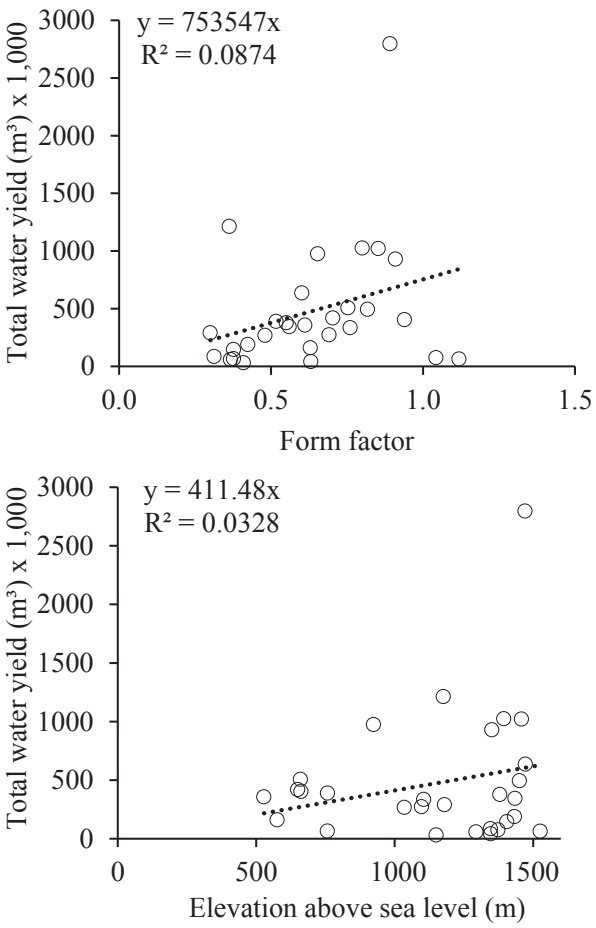

Figure 3. Relationships between water yield and watershed characteristics in 29 watersheds. 
the change in the water from the unit area (hectares) is explained by variables ratio of elongation, form factor, slope and elevation $(P<0.05)$.

In some watersheds, there is a certain amount of continuous flow of water even during dry periods (base flow). A relationship between the constant flow rate and watershed characteristics was sought, nevertheless no significant relationship was found. Therefore, to standardize the amount of water yield coming from watersheds, calculation was also made by removing base flow from the total yield. In this way, the relationships between net water yields and watershed characteristics obtained were subjected to statistical analyses. The resulting regression model is given in equation 2 .

$$
W Y=-188575+4646.1 A+169.2 H
$$

The equation is significant at higher levels (Adjusted $R^{2}=0.92$ and $P<0.01$ ). The amount of water that will be estimated by equation 2 can be accepted as the surface water and this can be calculated by area and elevation variables in the study area for any watershed.

\section{DISCUSSION}

Understanding the relationship between watershed characteristics and water yield is important for the control and management of hydrologic processes. It can be aimed at understanding the relationship between watershed characteristics and total water yield or amount of water coming from a unit area, the base flow or peak flow values. Although Price (2011) stated that watershed geomorphology clearly affects the amount of water yield, in this study, a significant correlation in the confidence level of 95 percent between watershed attributes and runoff coefficient of watersheds or the amount of water yield of the unit area could not be found. Nevertheless, the effect of geomorphology on the total water yields was analyzed and meaningful models were acquired at alfa level of 0.01 . Unquestionably, a model based on runoff coefficient or water yield of the unit area, which eliminates the effect of the precipitation and area differences, would be more useful and easy to generalize for other regions. This attempt was not realized, although the model based on water yield for a local area is also useful for the regions having similar hydro-climatic zones and will provide a basis to make comparisons with other regions.

In the regression equation, which is developed for use in estimating the total water yield of watersheds, it is determined that mean slope, ratio of circularity and drainage density have a low impact and when these are subtracted from the models, an increased significance of the equation is observed. Bao and Laituri (2013) stated that they did not monitor any effect on flow indices of the average watershed mean slope; they also indicated that the average mean slope is not a good topological index. The index of form factor is reported to be more effective on peak flow and lag time (Özhan 2004).

It is implied that form factor has significant effects on variations of stream flows and that irregular shapes lead to higher values of daily flow variability (Bao and Laituri 2012). Goff and Gentry (2006) reported a significant effect of form factor on detention ponds in watersheds. Moreover, this situation affects the total water yield of watersheds and in the developed equation, it has been observed that the form factor has a significant effect on total water yield.

With the increase of drainage density, flow channel and thus the contribution of subsurface flow (interflow and base flow combined) to total water yield are reported to increase (Yıldız 2004). Similarly, Carlston (1963) asserted that there is a close relationship between the amount of annual surface flow and drainage density in per area and suggested that the drainage network in the watershed indicates that the average flow adjusted to this relationship. On the contrary, a significant impact of drainage density on the annual water yield in watersheds was not observed in this study. This factor might not have emerged as a prominent feature since watersheds are small and thus drainage networks are similar and nearly all of them are covered by forests.

Bao and Laituri (2013) stated there is a common belief that the size of the watershed is effective on hydrological features, although in the study they carried out, they could not find a significant relationship between size of the watershed and hydrological processes in the confidence level of 95 percent. Özhan (2004) stated that as the watershed grows, the volume and yield of surface flows can increase, nevertheless this can also reduce the amount expected to flow from the unit area. According to our findings, the watershed area has emerged to be the most effective watershed characteristic on total water yield. On the other hand, also a positive effect of mean elevation above sea level and ratio of elongation on water yield can be seen. The reason for the effect of elevation may be the increase of annual precipitation based on altitude. Salloum (2015) states that in defining the morphology of the watershed, ratios of elongation and circularity alone are not sufficient and that they might both be evaluated together for more accurate results. These factors are effective on the concentration time of rainwater in the watershed and peak flows. When the ratio of elongation is high and ratio of circularity is low, infiltration of water increases and this ensures the regular flow of the rivers throughout the year (Gajbhiye 2015). In the study, an autocorrelation between ratio of circularity and elongation was observed and by extracting the ratio of circularity we obtained a model which is more significant.

\section{CONCLUSIONS}

The relation between water yield and watershed characteristics was carried out by regression analyses. While the area of the watersheds, form factor and elevation have positive effects on water yield, ratio of elongation has a negative effect for the model as a whole. When base flows are not considered, a significant model was obtained, although the variables that are effective were changed. Only area and elevation can explain the variation with 
an important ratio in this model. In the study area, highmountainous watersheds are largely covered by forests; therefore, hydrological processes must be taken into consideration when making wood production in these areas. The resulting equations will be useful for forest management and planning in terms of determining the priorities of watersheds or estimating the amount of water production. In addition, some indices can be generated by using watershed characteristics to evaluate suitability of watersheds in terms of water production. However, watershed characteristics are constant and not manageable, they can be easily calculated and serve to estimate water yields. Furthermore, they can be integrated to some other models with many manageable variables such as tree volume, basal area etc. Together with this, more and repeated hydrology studies in various regions and association of the studies with other factors such as forest structure affecting the hydrological cycle will ensure that they are applied in practice and will expand their areas of utilization.

In some other areas presenting different climate or geology, the extent and direction of the relations can change. Thus, more research on different ecological regions with different point of views is needed for widely usage of these kinds of models.

\section{ACKNOWLEDGEMENT}

This work was supported by The Scientific and Technological Research Council of Turkey (TUBITAK), with Project ID: TOVAG-213O199. We also thank to Chiefs of the Duzce Forest Enterprise for their collaboration on field.

\section{REFERENCES}

Bao TR, MJ Laituri. 2013. The effects of watershed characteristics on storm runoff relationships in Vietnam. Journal of Environmental Science \& Water Resources 2(2):40-52.

Bisantino T, R Bingner, W Chouaib, F Gentile, G Trisorio Liuzzi. 2015. Estimation of runoff, peak discharge and sediment load at the event scale in a medium-size mediterranean watershed using the AnnAGNPS model. Land Degradation and Development 26(4): 340-355.

Bosch JM, JD Hewlett. 1982. A review of catchment experiments to determine the effect of vegetation changes on water yield and evapotranspiration. Journal of Hydrology 55: 3-23.

Carlston CW. 1963. Drainage Density and Streamflow. Physiographic and Hydraulic Studies of Rivers. Geological Survey Professional Paper 422-C. Washington, USA. Government Printing Office. 13 p.

Çepel N. 1993. Toprak-Su-Bitki İlişkileri, İÜ Orman Fakültesi Yayını, İ.Ü. Yayın No: 3794/5. Istanbul, Turkey.

Gajbhiye S. 2015. Morphometric analysis of a Shakkar river catchment using RS and GIS. International Journal of $u$ - and e-Service, Science and Technology 8(2): 11-24.
Goff KM, RW Gentry. 2006. The influence of watershed and development characteristics on the cumulative impacts of storm water detention ponds. Water Resources Management 2: 829-860.

Kotak BG, A Selinger, B Johnston. 2005. Influence of watershed features and disturbance history on water quality in boreal shield streams and rivers of Eastern Manitoba. Manitoba Model Forest Report 04-2-63. Little Black Rive, Canada. Black River First Nation. 161 p.

Meraj G, SA Romshoo, AR Yousuf, S Altaf, F Altaf. 2015. Assessing the influence of watershed characteristics on the flood vulnerability of Jhelum Watershed in Kashmir Himalaya. Natural Hazards 77(1): 153-175.

Özhan S. 2004. Havza Amenajmani. Istanbul University Faculty of Forestry Publication No: 481. ISBN 975-404-739-1. 384 p.

Özmen B. 2000. Düzce-Bolu Bölgesi'nin Jeolojisi, Diri Faylari ve Hasar Yapan Depremleri. In Özmen B, G Bağci eds. 12 Kasım 1999 Düzce Depremi Raporu. Bayindirlik ve Iskan Bakanligi Afet Isleri Genel Mudurlugu, Deprem Arastirma Dairesi. Ankara, Turkey. p. 1-14.

Pilgrim DH, I Cordery, BC Baron. 1982. Effects of catchment size on runoff relationships. Journal of Hydrology 58(3-4): 205-221.

Price K. 2011. Effects of watershed topography, soils, land use, and climate on baseflow hydrology in humid regions: A review. Progress in Physical Geography 35(4): 465-492.

Price K, CR Jackson, AJ Parker, T Reitan, J Dowd, M Cyterski. 2011. Effects of watershed land use and geomorphology on stream low flows during severe drought conditions in the Southern Blue Ridge Mountains, Georgia and North Carolina, United States. Water Resources Research 47(W02516): 1-19.

Roberts AD. 2016. The effects of current landscape configuration on streamflow within selected small watersheds of the Atlanta metropolitan region. Journal of Hydrology: Regional Studies 5: 276-292.

Salloum G. 2015. Elongation and circularity concepts, and watersheds ordering systems: A morphometric study. Damascus University Journal 31(3):25-26 (For the paper in Arabic see pages (341-373).

Sun G, SG McNulty, J Lu, DM Amatya, Y Liang, RK Kolka. 2005. Regional annual water yield from forest lands and its response to potential deforestation across the Southeastern United States. Journal of Hydrology 308: 258-268.

Yavuz R. 2013. Fertilizer and herbicide applications for rangeland rehabilitation (Düzce Köprübaşı Ömerefendi case study). PhD Thesis. Düzce, Turkey. Düzce University. 179 p.

Y1ldiz O. 2004. An investigation of the effect of drainage density on hydrologic response. Turkish Journal of Engineering and Environmental Sciences 28: 85-94.

Yıldız O, D Eşen, OM Karaoz, M Sargıncı, B Toprak, Y Soysal. 2010. Effects of different site preparation methods on soil carbon and nutrient removal from eastern beech regeneration sites in Turkey's Black Sea Region. Applied Soil Eco$\log y$ 45(1): 49-55.

Yuan Y, Y Jiang, EV Taguas, EG Mbonimpa, W Hu. 2015. Sediment loss and its cause in Puerto Rico watersheds. Soil 1: 595-602. 